Article

\title{
Increasing Sustainability of Residential Areas Using Rain Gardens to Improve Pollutant Capture, Biodiversity and Ecosystem Resilience
}

\author{
Jennifer Morash ${ }^{1}$, Amy Wright ${ }^{2, *}$, Charlene LeBleu ${ }^{3}$, Amanda Meder ${ }^{1}$, Raymond Kessler ${ }^{1}$, \\ Eve Brantley ${ }^{4}\left(\mathbb{D}\right.$ and Julie Howe ${ }^{5}$ (D) \\ 1 Department of Horticulture, Auburn University, Auburn, AL 36849, USA; cjmorash@gmail.com (J.M.); \\ amanda.meder@gmail.com (A.M.); kessljr@auburn.edu (R.K.) \\ 2 College of Agriculture, Auburn University, Auburn, AL 36849, USA \\ 3 Program of Landscape Architecture, Auburn University, Auburn, AL 36849, USA; leblecm@auburn.edu \\ 4 Department of Crop Soil \& Environmental Science, Auburn University, Auburn, AL 36849, USA; \\ brantef@auburn.edu \\ 5 Department of Soil and Crop Sciences, Texas A\&M University, College Station, TX 77843, USA; \\ j-howe@tamu.edu \\ * Correspondence: wrigham@auburn.edu
}

Received: 14 May 2019; Accepted: 10 June 2019; Published: 13 June 2019

\begin{abstract}
Rain gardens have become a widespread stormwater practice in the United States, and their use is poised to continue expanding as they are an aesthetically pleasing way to improve the quality of stormwater runoff. The terms rain garden and bioretention, are now often used interchangeably to denote a landscape area that treats stormwater runoff. Rain gardens are an effective, attractive, and sustainable stormwater management solution for residential areas and urban green spaces. They can restore the hydrologic function of urban landscapes and capture stormwater runoff pollutants, such as phosphorus (P), a main pollutant in urban cities and residential neighborhoods. Although design considerations such as size, substrate depth, substrate type, and stormwater holding time have been rigorously tested, little research has been conducted on the living portion of rain gardens. This paper reviews two studies-one that evaluated the effects of flooding and drought tolerance on the physiological responses of native plant species recommended for use in rain gardens, and another that evaluated $\mathrm{P}$ removal in monoculture and polyculture rain garden plantings. In the second study, plants and substrate were evaluated for their ability to retain $\mathrm{P}$, a typical water pollutant. Although plant growth across species was sometimes lower when exposed to repeated flooding, plant visual quality was generally not compromised. Although plant selection was limited to species native to the southeastern U.S., some findings may be translated regardless of region. Plant tissue $\mathrm{P}$ was higher than either leachate or substrate, indicating the critical role plants play in P accumulation and removal. Additionally, polyculture plantings had the lowest leachate $\mathrm{P}$, suggesting a polyculture planting may be more effective in preventing excess $\mathrm{P}$ from entering waterways from bioretention gardens. The findings included that, although monoculture plantings are common in bioretention gardens, polyculture plantings can improve biodiversity, ecosystem resilience, and rain garden functionality.
\end{abstract}

Keywords: rain gardens; bioretention; monoculture; polyculture; substrate; phosphorus; low impact development; green infrastructure 


\section{Introduction}

The negative impacts of urbanization on associated watersheds result in changes to hydrology, elevated concentrations of nutrients and contaminants, altered channel morphology, and reduced biodiversity [1]. Urbanization also decreases groundwater recharge, which often leads to diminished groundwater supply [2]. Contributors to altered watersheds and reduced groundwater reserves are numerous, but the primary driver is stormwater runoff. Beyond changes to natural hydrology, stormwater is also associated with pollution [3]. Stormwater carries pollutants and discharges them to surface waters. Pollutants include: Heavy metals (such as lead, zinc, copper, and cadmium), polycyclic aromatic hydrocarbons, soluble salts, pesticides, nitrogen, solids, pathogens, pharmaceuticals, and $\mathrm{P}$. Phosphorus, a main pollutant in urban areas, enters waterways with surface water runoff degrading the waterways through over production of algae and aquatic plant growth [4-11]. The main source of urban $P$ is residential lawns and streets.

\subsection{Low Impact Development}

Low impact development (LID) has gained popularity as a tool to increase local sustainability, resiliency and improve ecosystem health [4-7,12-14]. LID uses an approach that mimics natural hydrology practices through small, site-scale, cost-effective landscape features that soak up, hold, convey, and filter stormwater onsite $[7,12,15,16]$. These localized stormwater control measures (SCMs) include rain gardens, bioretention, porous paving, grass swales, green roofs and more. LID enhances the local environment, protects public health, improves community livability, and can save residential developers and local governments money by reducing construction costs [15,17-21]. The United States Environmental Protection Agency (US EPA) has reported that traditional curb and gutter, storm piping, and detention ponds of residential developments can cost two to three times as much as grass swales and other LID techniques [7]. However, the key factor in the success of LID at the residential scale is to ensure that the SCMs are attractive, low maintenance, and perceived by the property owner as adding ecological value to the property $[12,15]$.

\subsection{Rain Gardens}

Rain gardens are an effective LID practice used in residential areas to capture stormwater runoff, recharge groundwater through infiltration, and remove runoff pollutants, such as phosphorus $(\mathrm{P})$ from stormwater prior to entering local streams [6,22-28]. Rain gardens add ecological value to residential developments by filtering nutrients, metals and pathogens from stormwater runoff. Rain gardens are known to filter around 90 percent of copper, lead and zinc; 50 percent of nitrogen; and $65 \%$ of $\mathrm{P}$, which could otherwise flow into storm drains and eventually bodies of water $[29,30]$. Nitrogen $(\mathrm{N})$ and $\mathrm{P}(\mathrm{P})$ are of particular concern and interest in urban stormwater runoff due to their role in eutrophication of water bodies, onset of harmful algal blooms, and fish kills [13,31,32]. Traditionally, a rain garden is constructed as a shallow depression in the landscape that receives runoff during a storm event. Trees, shrubs, and herbaceous landscape plants are planted along with a groundcover or mulch layer $[5,33,34]$. Rain gardens are designed to experience periodic flooding for up to two days [23,35]. A maximum of $48 \mathrm{~h}$ is recommended to prevent mosquitoes from breeding [36] and prolonged exposure of plant roots to anaerobic conditions [37]. Rain gardens are watered naturally and therefore may experience very dry conditions as well as the expected temporary flooded conditions [38-40].

\subsection{Flooding Tolerance}

Flooding imposes a substantial abiotic stress on plants that often affects growth, distribution, and productivity [41]. The major stress on flooded plants is an inadequate supply of oxygen to submerged tissues [42]. Gas diffusion is severely inhibited in flooded soils. Within 24 to $48 \mathrm{~h}$ of flooding, plant roots deplete soil oxygen and exhibit root stress [43]. Eventually, toxic products of anaerobic metabolism accumulate, causing harm to plant cells. Plants unable to withstand flooding stress eventually succumb 
to depleted carbohydrate reserves, accumulation of toxic metabolites, hormonal dysfunction, or some combination of the above. Even after flooding subsides, a plant is susceptible to post-anoxic injury as it is reintroduced to oxygen [44]. Susceptibility to secondary biotic stresses, such as pests and abiotic stresses, and wind and temperature, can also be problematic for waterlogged plants.

Flood tolerant plants overcome flooding stress through a suite of morphological and physiological adaptations [41,42]. Flooding often limits plant size. Therefore, injuries to roots, shoots, and leaves are evidence of plant fitness during and after a flooding event. Initial and final plant dry weight, total leaf area, and other growth measures are good indications of a plant's tolerance to flooding [45]. Long-term flooding adaptations often develop in the roots. Original roots may dieback and be replaced by adventitious roots [46]. The ratio of dead to living root tissue may be compared to other root systems. Leaf yellowing, or chlorosis, and death is a common injury caused by flooding [47]. Leaf yellowing due to flooding resembles nitrogen deficiency, however, it often appears 4-6 days after flooding occurs. Finally, a decrease in stomatal conductance during flooding is also common since flooding can cause a decrease in the capacity of plants to absorb and conduct water [47]. Stomatal conductance can be measured to determine how much water vapor is being emitted via the stomata [48-50]. Understanding the degree to which a plant can withstand wet or dry conditions is important in determining rain garden plant effectiveness. Furthermore, such knowledge helps determine proper rain garden placement.

\subsection{Phosphorus}

Plant species tolerant of flooding will generally acquire more nutrients in their plant tissue than flood-intolerant species [51,52]. In some cases, waterlogged soils can increase the ability of plants to uptake Ps and increase the soil $\mathrm{P}$ availability [53]. However as previously discussed, plants may face reductions in growth, biomass, and photosynthetic activity when waterlogged [52]. In turn, the release of soil P during flooding events can act as a nutrient source or sink [54]. As such, repeated flooding can result in a P release from soils, which introduces additional $P$ to soils and waterways $[54,55]$. Plant selection is key to rain garden functionality-not only in terms of plant survival but in regards to nutrient removal.

\subsection{Plant Selection}

While studies have been conducted regarding the design and substrate composition of rain gardens to maximize capture potential and pollutant retention [56,57], research on rain garden plant selection is sparse. In light of limited rain garden plant research, initial studies focused on plant selection. Most of the research was conducted in southeastern U.S.A. [58-62]. Findings are summarized in Appendix A. The results of some studies found that not all plants commonly recommended for rain garden inclusion responded well to evaluation, which indicates that continued area specific rain garden plant research is needed. The results also suggest that research should not be limited to plant selection. For example, Clethra alnifolia L. Ruby Spice (Ruby Spice summersweet) did poorly in one study [60], but thrived in another study [58]. The difference in performance was attributed to plant size. Larger plants $(3.8 \mathrm{~L})$ seemed more tolerant of flooding than smaller plants $(1 \mathrm{~L})$ possibly due to more robust root systems. If true, initial plant size should be considered when installing a rain garden. Dylewski (2012) [60] noted that plant maturity also affected flooding tolerance. In that study Itea virginica L. Henry's Garnet (Henry's Garnet sweetspire) demonstrated decreased sensitivity to flooding with greater plant maturity. However, the opposite was true for Vibrurnum nudum (L.) A. Gray (Shamrock inkberry holly). A greater understanding of individual plant performance at various stages of life, exposure, and nutrient inundation would benefit those designing and implementing rain garden systems.

Polyculture planting is another important consideration. Research suggests that using a variety of plant species benefits functionality. Diversifying planting composition between functional groups-monocots and dicots, evergreen and deciduous, and shallow and deep-rooted species-can increase competition for nutrients, biomass productivity, and stress tolerance [63-65]. Polyculture 
planting could also increase competition in water uptake and thereby increase flooding tolerance and nutrient uptake and removal $[59,64,66]$. Those researchers concluded that nutrients were released during cool season perennial die back, even when evergreens were present. Nevertheless, evergreens likely helped increase nutrient uptake during the cool season. The same study noted high tissue concentrations of metals in ferns. Ferns may, in turn, have potential for greater metal uptake and removal from rain garden systems. Additionally, polyculture plantings demonstrated greater potential to remove niche nutrients and thereby increase overall nutrient removal [67-70]. Combined, the current research suggests that polyculture planting could increase overall rain garden performance through greater nutrient uptake, avoid seasonal vegetative gaps, and increase water uptake.

\subsection{Objective}

Characterization of plant health in response to short-term cyclic flooding is critical when evaluating plants for inclusion in rain gardens. Although many plants have been recommended for use in bioretention gardens, data are needed to document plant establishment, flood tolerance, and P uptake under repeated short-term flooding conditions. Plant selection for the two studies discussed in this paper was based on published recommendations [38,71,72] and included grasses, shrubs, an herbaceous perennial, and ferns.

Therefore, the first objective of this research was to evaluate five diverse native landscape plant species for tolerance to repeated short-term flooding. The second objective was to evaluate three diverse native landscape plant species for $\mathrm{P}$ uptake and tolerance of bioretention garden conditions and to compare monoculture and polyculture planting combinations of these same species.

\section{Materials and Methods}

\subsection{Rain Garden Microcosms}

Rain garden microcosms were constructed using $97 \mathrm{~L}$ plastic nursery containers [Classic 10,000, Nursery Supplies, Inc. (Chambersburg, PA, USA)]. One 97 L container represented one microcosm. Two types of containers were utilized: (1) Containers lacked drainage holes and could be flooded and (2) containers drained freely though drainage holes stamped by the manufacturer on the bottom of each container. Containers without drainage holes were modified with a drainage valve to allow for repeated flooding and draining. Microcosms were placed under an outdoor shade structure at the Paterson Horticulture Greenhouse Complex, Auburn University, AL. The top of the structure was covered with a double layer of 6 mil clear polyethylene plastic to exclude rainfall and 60\% woven shade cloth to allow for evaluation of shade plants. The structure was constructed with an overhead sloped frame to allow the water to drain off.

\subsection{Growth and Physiological Response Study}

Five shade-tolerant southeastern U.S.A. native plant species, including two evergreen shrubs, two ferns, and one herbaceous perennial, were selected for this study, and the physiological responses to repeated short-term flooding were examined. All species are commonly recommended for use in rain gardens [35,71,72]. Shrubs included 11.3 L Illicium floridanum Ellis (Florida anise) and Morella cerifera L. (wax myrtle) (Figure 1). Ferns included 3.8 L Osmunda cinnamomea L. (cinnamon fern) and Polystichum acrostichoides Michx. (Christmas fern). The perennial used in the study was $3.8 \mathrm{~L}$ Chasmanthium latifolium Michx. (river oats). These sizes correspond to the sizes typically available commercially for these species for planting into a landscape. Each species was included in two experimental runs with the exception of $C$. latifolium which was included in three experimental runs. 


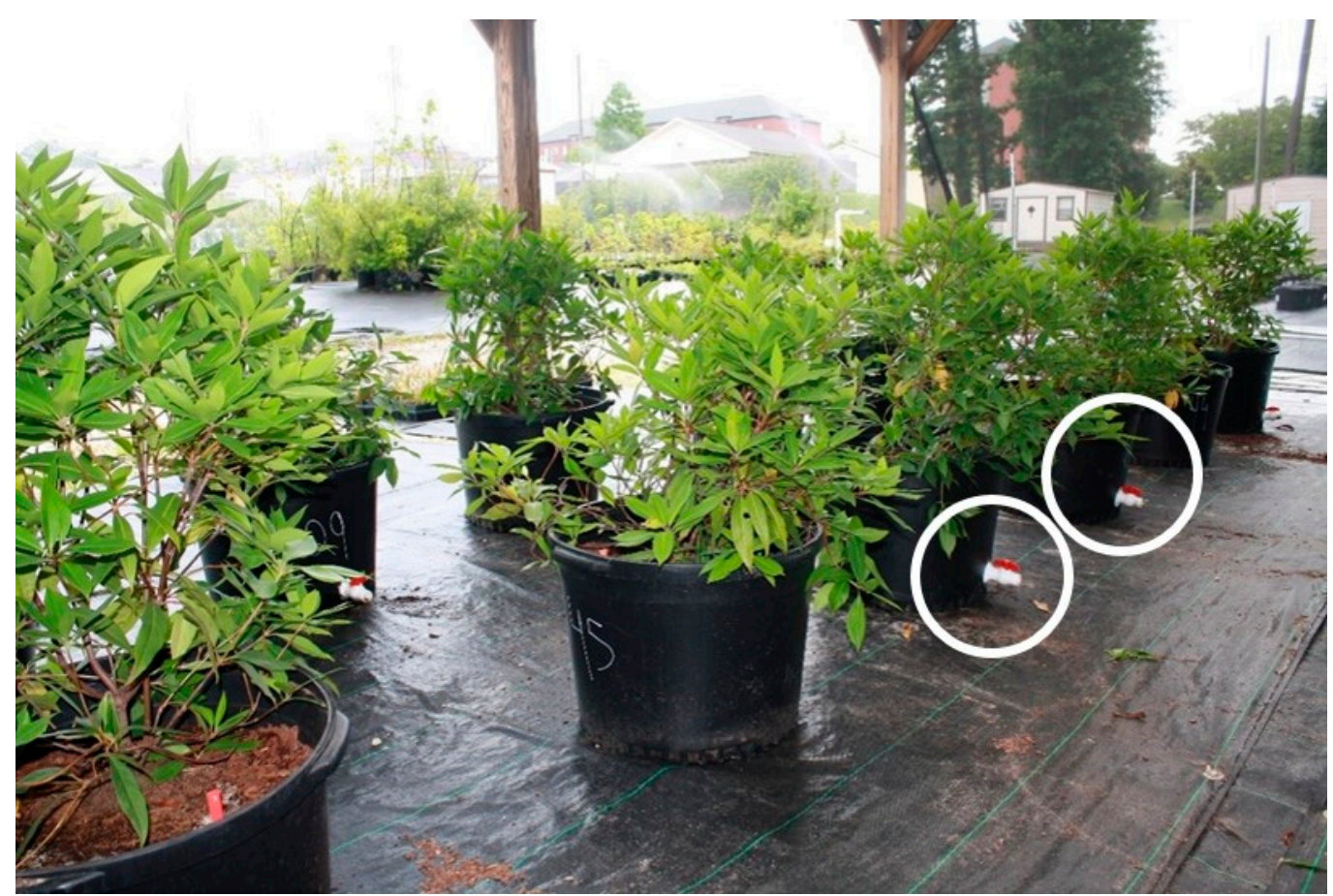

Figure 1. Shrubs Illicium floridanum (Florida anise) planted in microcosms under shade and rain exclusion. Microcosms equipped with valves (circled) could be flooded for $48 \mathrm{~h}$, while other microcosms had traditional drainage holes.

Rain garden microcosms were filled with an 8:1 pine bark:sand substrate amended with $1.2 \mathrm{~kg} / \mathrm{m}^{3}$ of dolomitic limestone and $8.0 \mathrm{~kg} / \mathrm{m}^{3}$ of $15 \mathrm{~N}-3.9 \mathrm{P}-10 \mathrm{~K}$ Osmocote Plus (with micronutrients, Marysville, $\mathrm{OH}, \mathrm{USA}$ ). A slow-release fertilizer was used to avoid mass leaching during flooding inundation [73]. Shrubs were planted one plant per microcosm. One perennial species was planted per microcosm. One of each fern species was planted per microcosm (total of two plants per microcosm for ferns).

Plants received one of two treatments-flooded or non-flooded. Flooded plants were flooded by hand watering the container until inundated and adding water as needed to maintain flooded conditions for $48 \mathrm{~h}$ followed by 5 days of draining (no additional water added). During flooding, water level was maintained approximately $2 \mathrm{~cm}$ above the substrate to ensure complete inundation. Plants were flooded once weekly for 8 weeks. Non-flooded plants were hand watered every other day with approximately $11 \mathrm{~L}$ of water. All plants were harvested after 8 weeks.

Three additional plants of each species were destructively harvested at a study initiation to determine initial size index (SI) [(height + widest width + width perpendicular the widest width)/3], leaf area [LA, LI-3100 leaf area machine (LI-COR, Inc. Lincoln, NE, USA)], and shoot dry weight (SDW) [leaf + stem dry weight]. For SDW, plant tissue was placed in a $77^{\circ} \mathrm{C}$ drying oven for 3 days and weighed immediately upon removal.

Initial SI and final SI, LA, and SDW were collected for plants in the microcosms. Final LA was measured for all ferns and perennials. For the shrubs, final LA was measured for three plants per species per treatment. Leaf chlorophyll content [LCC, Konica Minolta Chlorophyll Meter SPAD-502Plus (Ramsey, NJ, USA)] and stomatal conductance [SC, Decagon Devices, Inc. Leaf Porometer (Pullman, WA, USA)] were measured from newly matured leaves at the end of draining (five days no water) and flooding $(48 \mathrm{~h})$ periods. For shrubs in both runs of the experiment and the first experimental run of perennials, LCC and SC was measured beginning midway through an experimental run and continuing for the last 3 weeks. For the ferns and second experimental run of perennials, LCC and SC was measured at 2, 4, 6, and 8 weeks. Stomatal conductance was measured between 8:00 a.m. and 11:00 a.m. for morning measurements and between 1:00 p.m. and 3:00 p.m. for afternoon measurements. 


\subsection{Phosphorus Retention Study}

Three southeastern U.S.A. native plants species including a grass, an herbaceous perennial, and an evergreen shrub were used for this study, which examined the P uptake by plants and P retention by the substrate. Plants of Andropogen ternarius Michx. (splitbeard bluestem), Coreopsis verticillata Zagreb L. Glab. (whorled coreopsis), and Ilex vomitoria Schilling's Dwarf Ait. (yaupon holly) were removed from $38 \mathrm{~L}$ containers and replanted into microcosms, with three plants per microcosm. Four planting combinations were used. These included a monoculture of $A$. ternarius, $C$. verticillata Zagreb, or $I$. vomitoria Schilling's Dwarf (three plants of same species per microcosm) or a polyculture of $A$. ternarius, C. verticillata Zagreb, and I. vomitoria Schilling's Dwarf (one plant of each species per microcosm), with 12 microcosms per planting combination (three monocultures and one polyculture). Microcosms were filled with a substrate of a $50 \%$ sand, $25 \%$ pine bark, $25 \%$ peat moss, amended with $0.45 \mathrm{~kg} \cdot \mathrm{m}^{-3} \mathrm{P}$ free $19 \mathrm{~N}-0 \mathrm{P}_{2} \mathrm{O}_{5}-17 \mathrm{~K}_{2} \mathrm{O}$ (with micronutrients) (Tru-prill, Plant Science, Inc, Gormley, ON, Canada). This substrate was chosen to simulate bioretention substrates suggested for use in LID projects [26,74-76].

After one week of acclimation outdoors, flood and non-flood treatments were initiated. Plants were irrigated (non-flood) or flooded with a solution containing $1.6 \mathrm{mg} \cdot \mathrm{L}^{-1} \mathrm{P}\left(85 \% \mathrm{H}_{3} \mathrm{PO}_{4}\right.$, Fisher Scientific, Pittsburgh, PA, USA) which is four times the median P concentration of $0.4 \mathrm{mg} \cdot \mathrm{L}^{-1}$ in urban stormwater runoff $[25,27]$. Six microcosms from each planting combination were flooded with $26.5 \mathrm{~L}$ of solution, and no additional solution was added during each flood event of $48 \mathrm{~h}$. Following each flood event, the microcosm was drained for seven days. No additional water was added to the containers during the draining period of seven days that followed each flood event (flood-drain cycle). There were 12 flood-drain cycles. The non-flood microcosms, six from each planting combination, were irrigated three times weekly with $20 \mathrm{~L}$ of solution.

Size index [(shoot height + shoot widest width + shoot width (perpendicular to widest)/3)] was measured for each plant at initiation, midway, and termination. At termination, plant shoots were severed at the substrate surface, and roots were rinsed to remove substrate. Shoots and roots were dried separately in an oven for $48 \mathrm{~h}$ at $66^{\circ} \mathrm{C}$ to determine shoot dry weight and root dry weight. Four $50 \mathrm{~g}$ substrate samples were collected prior to planting. Upon termination, four $50 \mathrm{~g}$ substrate samples were collected for each planting combination $\mathrm{x}$ flood treatment. Also upon termination, the entire dried shoot or root tissue of three plants per planting combination $x$ flood treatment were ground to $5 \mathrm{~mm}$ particle size and a $0.5 \mathrm{~g}$ tissue sample collected from each. Leachate samples $(200 \mathrm{~mL})$ were collected from three containers in each planting combination $\mathrm{x}$ flooding treatment using the Virginia Tech Pour Through Method [77]. Substrate samples were processed using Mehlich 1 double acid extraction method, and tissue samples were processed using dry ash and double acid extraction method by the Auburn University Plant and Soil Analysis Lab [78]. Leachate, substrate and tissue samples were analyzed for P concentrations for at Auburn University Plant and Soil Analysis Lab using Inductively Coupled Plasma (ICP) spectrophotometer.

Two experimental runs were conducted. The first run was initiated 27 September 2012 and terminated 7 December 2012 (herein referred to as fall). The second run was initiated 4 April 2013 and terminated 7 June 2013 (herein referred to as spring). There were no differences in methodology between runs, except that chemical analysis of root and shoot tissue, substrate, and leachate was conducted in fall only. Microcosms (flood or non-flood) and planting combinations were completely randomized.

\subsection{Statistical Analysis}

For both studies, analysis of variance was performed using PROC GLIMMIX in SAS version 9.3 (SAS Institute, Cary, NC, USA), and microcosms were arranged in a completely randomized design with six microcosms per treatment per species (or planting combination). For the physiology study, each species was treated as a separate experiment. For the P study, treatments were in a factorial treatment design of species (planting composition) and flood. All significances were at $P=0.05$. The results for main effects and interactions are presented when significant, and not presented if not significant. If interactions were significant, then the simple effects of each factor are presented. The 
means separation was performed using Tukey for the growth and physiology study and LSMEANS for the P retention study.

\section{Results}

\subsection{Growth and Physiological Response Study}

\subsubsection{Plant Response to Short-Term Cyclic Flooding}

With the exception of P. acrostichoides, all species evaluated tolerated intermittent flooding (Table 1). Two of the six flooded P. acrostichoides plants died, and SI, LCC, and SC were lower in flooded plants than in non-flooded plants of this species in the summer 2015 run. In some ways, data for I. floridanum did not support personal observations. Growth measurements (SI, LA, DW) showed a tolerance of short-term cyclic flooding. However, physiological measurements and personal visual observations did not. Leaf yellowing, wilting, and senescence increased as the experiment progressed. Regarding the five plant species evaluated, C. latifolium tolerated flooding best, based on data collected and personal visual observations. The results were higher for flooded plants of this species in at least one measurement for each run, especially during summer runs.

Table 1. Summary of responses to 7-8 weeks of cyclic flooding for five species: Illicium floridanum (IF), Morella cerifera (MC), Osmunda cinnamomea (OC), Polystichum acrostichoides (PA), and Chasmanthium latifolium (CL). The experiment was conducted in Auburn, AL. Runs included summer 2014 (SU 14), fall 2014 (FA 14), spring 2015 (SP 15), and summer 2015 (SU 15). Measurements included: size index (SI), leaf area (LA), leaf chlorophyll content (LCC), shoot dry weight (SDW), leaf:stem DW ratio, and stomatal conductance (SC). Plants were flooded for $48 \mathrm{~h}$ followed by 5 days of no watering (flooded, F) or watered every other day (non-flooded, NF). If a difference occurred between species, the treatment with a higher value is highlighted.

\begin{tabular}{|c|c|c|c|c|c|c|c|}
\hline \multicolumn{8}{|c|}{ Growth and Physiological Study Results Summary } \\
\hline Type & Species & Run & $\mathrm{SI}^{\mathrm{z}}$ & LA & LCC & SDW & SC \\
\hline \multirow{4}{*}{ Shrub } & \multirow{2}{*}{ IF } & SU 14 & $\mathrm{ND}^{\mathrm{y}}$ & ND & ND & ND & NF \\
\hline & & FA 14 & ND & ND & NF & ND & NF \\
\hline & \multirow{2}{*}{$\mathrm{MC}$} & SU 14 & NF & ND & ND & ND & NF- \\
\hline & & FA 14 & ND & ND & NF & ND & NF \\
\hline \multirow{4}{*}{ Fern } & \multirow{2}{*}{ OC } & SP 15 & ND & ND & ND & ND & ND \\
\hline & & SU 15 & ND & ND & ND & ND & ND \\
\hline & \multirow[b]{2}{*}{ PA } & SP 15 & ND & ND & ND & ND & $\mathrm{F}$ \\
\hline & & SU 15 & NF & ND & NF over time & ND & NF- \\
\hline \multirow{3}{*}{ Grass } & \multirow{3}{*}{ CL } & SU 14 & ND & $\mathrm{F}$ & $\mathrm{ND}$ & ND & $\mathrm{F}$ \\
\hline & & SP 15 & ND & ND & NF & ND & ND \\
\hline & & SU 15 & $\mathrm{~F}$ & $\mathrm{~F}$ & ND & $\mathrm{F}$ & ND \\
\hline
\end{tabular}

${ }_{\mathrm{z}} \mathrm{SI}=($ height + widest width + perpendicular width $) / 3 ;{ }^{\mathrm{y}}$ No significant difference is denoted by ND.

\subsubsection{Whole-Plant Stomatal Conductance Estimates}

In addition to the growth and physiological response measurements, whole-plant stomatal conductance estimates were calculated. Stomatal conductance was multiplied by leaf area to estimate the potential total amount of water that could be transpired by each species per second. There were no differences between flooding treatments for M. cerifera and O. cinnamomea. Illicium floridanum and $P$. acrostichoides showed differences only during the summer when total transpiration was higher in non-flooded (Table 2). Conversely, C. latifolium showed differences during both summer runs when total transpiration was higher with flooding. 
Table 2. Whole plant transpiration rates calculated using stomatal conductance $\left(\mathrm{mmol} \cdot \mathrm{m}^{-2} \cdot \mathrm{s}^{-1}\right)$ and total plant leaf area $\left(\mathrm{m}^{2}\right)$ of Illicium floridanum (IF), Morella cerifera (MC), Osmunda cinnamomea (OC), Polystichum acrostichoides (PA), and Chasmanthium latifolium (CL) after 7-8 weeks of flooding. Plants were flooded for $48 \mathrm{~h}$ followed by 5 days of no watering (flooded, F) or watered every other day (non-flooded, NF). The experiment was conducted in Auburn, AL, U.S.A. in summer 2014 (SU 14), fall 2014 (FA 14), spring 2015 (SP 15) and summer 2015 (SU 15).

\begin{tabular}{ccccccccccc}
\hline & \multicolumn{8}{c}{ Whole Plant Transpiration $\left(\mathbf{m o l} \cdot \mathbf{s}^{-1}\right)$} \\
\hline \multirow{2}{*}{ Type } & Species & F & NF & F & NF & F & NF & F & NF \\
\cline { 2 - 12 } Shrub & IF & $18.4 \mathrm{a}^{\mathrm{z}}$ & $0.513 \mathrm{~b}$ & 0.097 & 0.201 & - & - & - & - \\
\cline { 2 - 12 } & MC & 0.242 & 0.527 & 0.131 & 0.186 & - & - & - & - \\
\hline \multirow{2}{*}{ Fern } & OC & - & - & - & - & 0.095 & 0.075 & 0.054 & 0.053 \\
\cline { 2 - 12 } & PA & - & - & - & - & 0.021 & 0.018 & $0.002 \mathrm{a}$ & $0.018 \mathrm{~b}$ \\
\hline Grass & CL & $0.141 \mathrm{a}$ & $0.047 \mathrm{~b}$ & - & - & 0.022 & 0.025 & $0.237 \mathrm{a}$ & $0.142 \mathrm{~b}$ \\
\hline
\end{tabular}

${ }^{\mathrm{z}}$ Letters indicate significant differences between treatments for each species within a run at $p<0.05$.

\subsection{Phosphorus Retention Study}

\subsubsection{Dry Weight and Size Index}

All species tolerated repeated short-term flooding regardless of whether planted as a monoculture or as a polyculture [61]. There was some seasonality associated with growth for all three species. For. C. vertcillata, SDW was higher in flooded than non-flooded treatments (Table 3). For I. vomitoria, SDW was greater in fall than spring. In contrast, SDW of C. verticillata was higher in spring than fall. Although flooding did not affect SI of A. ternarius and I. vomitoria, SI of C. verticillata was higher in non-flooded than flooded (Table 3).

Table 3. Summary of responses to 15 weeks of cyclic flooding for three species: Ilex vomitoria (IV), Andropogon ternarius (AT), and Coreopsis verticillata (CV). The experiment was conducted in Auburn, AL. The runs included fall 2012 and spring 2013. The measurements included: size index (SI), shoot dry weight (SDW), and rood dry weight (RDW). The plants were flooded for $48 \mathrm{~h}$ followed by 7 days of no watering (flooded, F) or watered every other day (non-flooded, NF). If a difference occurred between species, the treatment with a higher value is highlighted.

\begin{tabular}{ccccc}
\hline Type & Species & SI $^{\mathbf{z}}$ & SDW & RDW \\
\hline Shrub & IV & ND & ND & ND \\
Grass & AT & ND & ND & ND \\
Perennial & CV & ND & NF & NF \\
\hline
\end{tabular}

${ }^{\mathrm{z}} \mathrm{SI}=\left(\right.$ height + widest width + perpendicular width) $/ 3 ;{ }^{\mathrm{y}}$ No significant difference is denoted by ND.

\subsubsection{Phosphorus Concentration}

Initial substrate $\mathrm{P}$ was $2.33 \mathrm{mg} / \mathrm{kg}$. The final substrate $\mathrm{P}$ was higher in flooded $(5.8 \mathrm{~g} / \mathrm{kg})$ than non-flooded $(7.5 \mathrm{mg} / \mathrm{kg})$. Similarly, leachate $\mathrm{P}$ was higher in flooded than non-flooded microcosms ranging from $13-15 \mathrm{mg} / \mathrm{L}$ in flooded to $6-7 \mathrm{mg} / \mathrm{L}$ in non-flooded. Root and shoot tissue $\mathrm{P}$ was highest among species in C. verticillata (Table 4). The concentration of $\mathrm{P}$ in root and shoot tissue along with the dry weight of root and shoot tissue, respectively, were used to calculate total phsophorus per plant. On a per plant basis, C. verticillata had $10.47 \mathrm{mg} \mathrm{P,} \mathrm{A.} \mathrm{ternarius} \mathrm{had} 101.71 \mathrm{mg}$ P, and I. vomitoria had $22.78 \mathrm{mg} \mathrm{P}$ in tissue. 
Table 4. Root and shoot tissue P concentrations (RTP and STP, respectively) of Ilex vomitoria (IV), Andropogon ternarius (AT), and Coreopsis verticillata (CV) after 15 weeks. Flooding did not affect RTP or STP. The experiment was conducted in Auburn, AL, U.S.A. in fall 2012 and spring 2013.

\begin{tabular}{cccc}
\hline Type & Species & RTP $(\mathbf{m g} / \mathbf{k g})$ & STP $(\mathbf{m g} / \mathbf{k g})$ \\
\hline Shrub & IV & $1607 \mathrm{~b}^{\mathrm{z}}$ & $2636 \mathrm{~b}$ \\
Grass & AT & $1945 \mathrm{~b}$ & $2443 \mathrm{~b}$ \\
Perennial & CV & $4089 \mathrm{a}$ & $3088 \mathrm{a}$ \\
\hline
\end{tabular}

${ }^{\mathrm{z}}$ Lowercase letters denote least squares mean separation among species within a column using ANOVA F-test in the Glimmix procedure $(p<0.05)$.

\section{Discussion}

\subsection{Plant Recommendations}

In order to provide a diverse list of research-based rain garden plant recommendations to meet varying needs and tastes, the Morash (2016) [62] and Meder (2013) [61] studies utilized plants from the following functional groups: Herbaceous perennial (C. verticillata), shrubs (I. vomitoria, M. cerifera and I. floridanum), ferns (P. acrostichoides and O. cinnamomea), and grasses (A. ternarius and C. latifolium). Plants were not evaluated long-term. Therefore, it is unknown if there would be an accumulation effect of prolonged stress, particularly for shrub species. Further, research did not include a winter experimental run. Rain garden soil may stay waterlogged for a longer period of time, and nutrient uptake and stomatal conductance rates are expected to be lower in cooler months. As such, the effects of winter intermittent flooding for the plants tested in these studies are not known.

O. cinnamomea was not affected by flooding during any run. Based on its response to simulated flooding and its visual appearance, O. cinnamomea is recommended for use in rain gardens. The following species were negatively affected by flooding during at least one run: $C$. verticillate (SI and SDW), I. vomitoria (SDW in combination planting), A. ternarius (SDW in combination planting), $M$. Cerifera (SI, LCC, and SC), I. floridanum (LCC and SC), and P. acrostichoides (SI, LCC, SC). Despite evidence of flooding stress, C. verticillate, I. vomitoria, M. cerifera, and A. ternarius appeared to tolerate the type of flooding expected in rain gardens and are therefore recommended for use in rain gardens. The results for I. floridanum were less clear. Although growth measurements (SI, LA, and SDW) suggested tolerance to short-term cyclic flooding, physiological measurements (LCC, SC) and personal visual observations (not quantified) did not. A likely explanation for the disparity relates to sample size. Destructive harvests were used for LA and DW. Due to time restrictions, only three plants of each shrub species per treatment were recorded. With such a small sample number, confidence intervals for detecting significant differences were large. A larger sample size could have decreased confidence intervals and increased precision [79]. In any case, results from these studies show the importance of coupling growth and physiological data with visual observations, seasonality, and survival to gain a full picture of a species suitability for use in a rain garden. Although leaf senescence and chlorosis are common symptoms in flooded plants, no previous research on flooding tolerance or drought tolerance was found for this species. Based on the results, it is unresolved whether to classify I. floridanum as suitable or unsuitable for use in southeastern U.S.A. rain gardens. The following species were benefited by flooding during at least one run: C. latifolium (every measurement) and P. acrostichoides (SC during the spring run). Based on experimental results, C. latifolium is an excellent southeastern U.S.A. rain garden plant. However, P. acrostichoides is not recommended for use in southeastern U.S.A. rain gardens without supplemental irrigation. Although the plant withstood rain garden conditions in the spring, results from the summer run suggest possible drought intolerance, which is a common rain garden condition. 


\subsection{Flooding and Seasonal Effects on Growth}

The Morash [62] and Meder [61] studies provide the opportunity to compare responses of different species within the same functional group to repeated short-term flooding. The conclusions based on growth measurements could help individuals implementing rain gardens make better plant selections after considering site-specific conditions. Both studies used the maximum flooding time recommended for rain gardens, $48 \mathrm{~h}$, and demonstrated that flooding affects plants differently within functional groups. For example, the Morash [62] study identified that $C$. latifolium, performed better under cyclic flooding, while Meder's results did not reveal a significant difference in growth measurements of A. ternarius when planted as a monoculture. Looking beyond these two studies, a third study that used a similar flooding technique and surveyed a native landscape grass, Muhlenberia capillaris (Lam.) Trin., found that SDW and root dry weight (RDW) was higher in non-flooded than flooded treatments (Christian et al., 2012). Comparing the results of the three studies establishes that plant tolerance to short term flooding cannot be assumed based on plant functional group. The results also provide rain garden implementers options for grass selection depending on the expected frequency of flooding.

Morash [62] made an interesting observation regarding flooded grass roots. Although RDW was not measured, Morash [62] described personal observations of the roots upon inspection of the plants at harvest. C. latifolium developed two characteristics not seen in any of the other species examined-robust root systems that penetrated the entirety of the $97 \mathrm{~L}$ containers in flooded plants and aerenchyma tissue in the stems. Aerenchyma are a well-known plant acclimation in waterlogged environments that transport oxygen to depleted roots [42]. Flood tolerant grass species, such as $C$. latifolium, can increase the number of adventitious roots per stem and nearly double root porosity [80]. Meder [61] provided similar observations for A. ternarius as well as data that support Morash's [62] observations. Mixtures of shallow and deep-rooted species can improve the uptake of limiting nutrients, such as $\mathrm{P}$, leading to higher productivity over time, and potentially, more nutrient removal from stormwater [64]. Therefore, the inclusion of deep-rooted plants, such as grasses as well as shallow rooted plants as herbaceous perennials, is recommended for rain gardens.

Like the grasses, the ferns demonstrated that plant recommendations should be based on site-specific conditions. Osmunda cinnamomea was very tolerant of rain garden conditions, and $P$. acrostichoides was not. Osmunda cinnamomea was not affected by flooding. Furthermore, the researcher stated that this species was visually appealing regardless of the treatment. Under the same flooding conditions, P. acrostichoides performed poorly. Flooding did not affect $P$. acrostichoides in the spring, but summer SI, LCC, and SC were negatively affected by flooding. Two of the six summer 2015 plants died. A time by flooding treatment interaction was found for LCC and SC, which suggest that a longer experimental period could have resulted in more loss. The researcher reported that plants seemed to suffer from the 5 days drying period and somewhat recover from drying when flooded. Intolerance for dry conditions may explain why this species was not negatively affected by flooding in the fall as opposed to the hot summer months. In a vegetative community study, P. acrostichoides was identified as a strong indicator species for the presence of near surface water (defined as saturated soil or water table within $30 \mathrm{~cm}$ ), which supports that this species was intolerant of the 5 days no watering period [81]. The results from $P$. acrostichoides emphasize the importance of rain garden research under various wet/dry periods as well as seasonal studies. Even though P. acrostichoides performed poorly in the rain garden simulation, it may succeed in areas with milder or wetter summers. Therefore, regional studies of rain garden plants are recommended for future research as well.

Growth measurements were helpful in identifying rain garden impacts on plants other than flooding, for example, the change in seasonality effects inevitable within a rain garden. When comparing runs of $C$. verticillata, the plant exhibited its highest growth measurements in the spring. The result is consistent with the typical growth pattern for $C$. verticillata, which predominately occurs during spring and summer [82]. Likewise, the growth of C. latifolium is also known to peak in the summer [83]. The average summer 2015, SDW of C. latifolium was more than 2.5 times higher than the spring 2015 average for both flooded and non-flooded plants (flooded spring:summer-31.3:82.1 
and non-flooded spring:summer-18.7:49.5). Shrubs exhibited a different growth pattern in both studies. All four shrub species grew throughout experimental runs including those conducted in fall, when growth typically peeks. Based on the evidence, monoculture planting or a planting of the same functional group (all grasses or all shrubs, for example), may result in vegetation gaps within seasons. If so, restrictions in nutrient uptake and transpiration rates would likely ensue. Furthermore, the general health of the rain garden could suffer. With a planting gap, another species, such as an invasive plant or weed, could move in more readily. Polyculture plantings are known to better resist invasion and are more resilient to mortality of another single species [84,85]. Having a variety of plants in a rain garden can reduce vegetation gaps caused by seasonal growth variations because successful species can take turns filling the gaps caused by unsuccessful species.

\subsection{The Effects of Polyculture on Growth and Phosphorus Uptake}

The Meder [61] study delved deeper into polyculture effects on growth. Polyculture planting in that study included three different functional plant groups-herbaceous perennial, shrub, and grass. Meder [61] revealed that polyculture treatment values, which were collected in the spring, were neither the highest in weight nor the lowest. Seasonal growth rates explain the intermediate dry weight of the polycultures. Andropogon ternarius and I. vomitoria were high growth species in fall, and C. verticillata was a high growth species in spring. Applying Meder's [61] results to a proper rain garden would mean that a rain garden populated by A. ternarius, I. vomitoria and C. verticillata would produce more biomass in the summer than a garden planted with only $C$. verticillata. Furthermore, had the polyculture experiment extended beyond one season, research suggests that it is likely that the average polyculture dry weights would have exceeded monoculture dry weights. A study of diversity and canopy structure on grassland ecosystems found that species and functional group diversity increased mean vegetation cover from $64 \%$ in monocultures to $100 \%$ in a 32 -species mixture [86]. The most species rich community produced $143 \%$ more biomass than monoculture plantings over several seasons. Plant functional group richness exerts positive effects on plant biomass and productivity. When competition exists between different functional groups, compared to within the same functional group, there is a higher biomass yield than when a functional group is grown alone, as the plants are occupying different resource niche spaces [64]. Therefore, by maximizing biomass through polyculture, greater nutrient uptake can likely be achieved.

The handling of $\mathrm{P}$ is of particular interest in rain gardens since it is known to be in high concentrations in urban runoff. Meder's study [61] provided insight into how different functional groups handled Pin monoculture and polyculture plantings. Slower growing plants from low-resource ecosystems, such as shade understory, have low capacity for nutrient uptake. This may explain why I. vomitoria, an understory shrub, had low shoot and root $\mathrm{P}$ concentrations [87-89]. Among species, root and shoot tissue P was highest in the perennial, C. verticillata, and similar in I. vomitoria (shrub) and A. ternarius (grass). Among planting combinations, root tissue $\mathrm{P}$ was also highest in C. verticillata monoculture pots, and the next highest root tissue $\mathrm{P}$ was in polyculture pots. Perennial plants from higher nutrient ecosystems, such as $C$. verticillata, may have higher nutrient uptake than faster growing plants, such as grasses $[90,91]$. Nutrient storage can occur in perennial plants as an insurance against future loss and as a support for growth when conditions are favorable, thus $C$. verticillata may have had the highest root and shoot tissue $\mathrm{P}$, due to its natural ability to take up more nutrients [87]. However, when total P for each plant was measured, C. verticuillata has the lowest total P uptake, which was 10 times lower than $A$. ternarius and 2 times lower than I. vomitoria. Furthermore, RDW was lowest for $C$. verticillata. In contrast, root tissue P was lowest for $A$. ternarius and I. vomitoria, and RDW was highest for $A$. ternarius. Thus, it is possible that while some species, such as $C$. verticillata, are storing excess $\mathrm{P}$ in plant tissue, species from low nutrient ecosystems or those with long life history traits, such as A. ternarius and I. vomitoria, may be allocating additional $\mathrm{P}$ to biomass production [87].

Lastly, Meder [61] examined how polyculture and flooding affected P in leachate. Leachate $\mathrm{P}$ was higher in flood treatments than in non-flood treatments. A similar study also found that $\mathrm{P}$ 
concentration in leachate was higher in flooded plants than non-flooded [59]. In non-flood treatments, leachate $\mathrm{P}$ was similar regardless of planting combination. When flooded, leachate $\mathrm{P}$ was lowest in polyculture plantings, which suggests there is more nutrient competition for $\mathrm{P}$ in polyculture plantings than monoculture plantings $[86,90,92]$.

\subsection{Stomatal Conductance in Rain Gardens}

Stomatal conductance was consistently higher in non-flooded plants than flooded plants in $I$. floridanum, M. cerifera, and P. acrostichoides (summer 2015 only). Stomata are known to close in response to flooding to prevent loss of oxygen $[93,94]$. However, in plants that are adapted to waterlogged soils, such as C. latifolium and P. acrostichoides, stomatal conductance can be enhanced (as it was in this research) by continuous flooding or periodic flooding [95]. Understanding evapotranspiration potential is an important consideration because transpiration modifies rain garden hydrology. Evapotranspiration can be nearly $50 \%$ of the hydrologic budget when shrubs were planted in rain gardens, which is consistent with the findings of this research [96]. Whole plant transpiration estimates for both shrub species were nearly double that of C. latifolium in the fall 2014 run. Therefore, transpiration rates may be considered when designing rain gardens. Utilizing plants with lower transpiration rates may result in longer drying times in a rain garden, but may also allow more infiltration for groundwater recharge. Conversely, plants with high transpiration rates may speed dry in areas where standing water may not be acceptable. Additionally, the inclusion of evergreen plants, such as the shrubs used in this research, promotes year round rain garden functionality [97].

\subsection{The Rain Garden Plant Selection Conundrum}

Regarding the eight species examined by the Meder [61] and Morash [62] studies, one plant was highlighted for its ability to adapt to flooding-Chasmanthium latifolium. This species not only tolerated repeated short-term flooding, but it responded positively to flooding based all of the data collected. Likewise, C. latifolium thrived in a complimentary three-year low-input performance study, which bolsters this plant's recommendation as an excellent rain garden selection [83]. Herein lies the case that a multitude of factors must be considered when choosing rain garden plants. While $C$. latifolium was proven to be hardy in low-input environments, tolerant of raingarden flooding, capable of higher transpiration rates when flooded, and prone to developing deep-rooted plants, especially when flooded, its ability to store $\mathrm{P}$ is likely lower than perennials from high nutrient environments. Once maximum height is achieved, the grass's ability to remove phosphorus could plummet. However, the transpiration rate would likely remain steady when flooded, even when fully mature. Therefore, no one plant is a catchall rain garden selection.

\section{Conclusions}

Implementers must choose the parameter most important to their system's success (for example transpiration in systems with expected high volumes of water or P uptake in systems with high nutrient inputs) from well researched rain garden recommendations. The Morash [62] and Meder [61] studies lay the groundwork for future rain garden plant studies and provide a method for simulating rain garden conditions with their use of microcosms in any region and with a range of plants species. Their research built a strong case for the use of polyculture in rain garden systems as well as six diverse species proven to tolerate fluctuating wet/dry periods in the southeastern U.S.A.

Author Contributions: Data curation, J.M., A.W. and A.M.; formal analysis, J.M., A.W., A.M., R.K., E.B. and J.H.; investigation, J.M. and A.M.; methodology, J.M., A.W., A.M., R.K., E.B. and J.H.; project administration, A.W. and C.L.; resources, A.W. and C.L.; supervision, A.W.; visualization, C.L.; writing一original draft, J.M., A.W. and C.L.; writing-review \& editing, J.M., A.W., J.H., and C.L.

Funding: This research was funded by the Alabama Agricultural Experiment Station, Auburn University, Auburn, AL, USA. 
Conflicts of Interest: The authors declare no conflicts of interest. The funders had no role in the design of the study; in the collection, analyses, or interpretation of data; in the writing of the manuscript, and in the decision to publish the results.

\section{Appendix A}

The following table summarizes rain garden plant recommendations for the southeastern U.S.A. based on research conducted at Auburn University, Auburn, AL.

Table A1. Southeastern U.S.A. native landscape plant species evaluated at Auburn University, Auburn, AL for tolerance to repeated short-term flooding. Species are classified as suitable or not for use in rain gardens based on the results of research similar to that described in this paper.

\begin{tabular}{|c|c|c|c|c|}
\hline Group & Plant & Suitable & Reference & $\begin{array}{l}\text { Additional } \\
\text { Comments }\end{array}$ \\
\hline \multirow{3}{*}{ Grass } & Andropogon ternarius broomsedge & $\mathrm{Y}$ & [61] & \\
\hline & Muhlenbergia capillaris muhly grass & $\mathrm{Y}$ & [59] & \\
\hline & Chasmanthium latifolium river oats & $\mathrm{Y}$ & {$[62]$} & \\
\hline \multirow{4}{*}{$\begin{array}{l}\text { Evergreen } \\
\text { Shrub }\end{array}$} & $\begin{array}{l}\text { Ilex vomitoria 'Schillings dwarf' } \\
\text { yaupon holly }\end{array}$ & & {$[59,60]$} & \\
\hline & Illicium floridanum Florida anise & Unknown & [62] & Poor visual quality \\
\hline & Morella cerifera wax myrtle & Y & [62] & \\
\hline & Ilex glabra 'Shamrock' inkberry & $\mathrm{Y}$ & {$[60]$} & \\
\hline \multirow{5}{*}{$\begin{array}{l}\text { Deciduous } \\
\text { shrubs }\end{array}$} & $\begin{array}{l}\text { Itea virginica 'Henry's Garnet' } \\
\text { sweetspire }\end{array}$ & & {$[60]$} & \\
\hline & $\begin{array}{l}\text { Viburnum nudum 'Winterthur' } \\
\text { possumhaw }\end{array}$ & Y & {$[60]$} & \\
\hline & $\begin{array}{l}\text { Fothergilla x intermedia 'Mt. Airy' } \\
\text { dwarf witch alder }\end{array}$ & $\mathrm{N}$ & [58] & Flood intolerant \\
\hline & $\begin{array}{l}\text { Ilex verticillata 'Winter Red' } \\
\text { winterberry }\end{array}$ & Y & {$[58]$} & \\
\hline & $\begin{array}{c}\text { Clethra alnifolia 'Ruby Spice' } \\
\text { summersweet }\end{array}$ & $\mathrm{Y} / \mathrm{N}$ & {$[58]$} & $\begin{array}{l}\text { Young plants not } \\
\text { suitable }\end{array}$ \\
\hline \multirow{2}{*}{ Perennial } & $\begin{array}{l}\text { Echinacea purpurea 'Magnus } \\
\text { Superior' purple cone flower }\end{array}$ & $\mathrm{N}$ & {$[61]$} & Flood intolerant \\
\hline & $\begin{array}{l}\text { Coreopsis verticillata 'Zagreb' } \\
\text { whorled coreopsis }\end{array}$ & Y & [61] & \\
\hline \multirow{2}{*}{ Fern } & $\begin{array}{c}\text { Osmunda cinnamomea cinnamon } \\
\text { fern }\end{array}$ & $\mathrm{Y}$ & {$[62]$} & \\
\hline & $\begin{array}{l}\text { Polystichum acrostichoides } \\
\text { Christmas fern }\end{array}$ & $\mathrm{N}$ & {$[62]$} & Drought intolerant \\
\hline
\end{tabular}

\section{References}

1. Walsh, C.J.; Roy, A.H.; Feminella, J.W.; Cottingham, P.D.; Groffman, P.M.; Morgan, R.P. The Urban Stream Syndrome: Current Knowledge and the Search for a Cure. J. N. Am. Benthol. Soc. 2005, 24, 706-723. Available online: https://pdfs.semanticscholar.org/1925/6fe11e5dcc29bed85d0710c59e196ea74e12.pdf (accessed on 2 May 2019). [CrossRef]

2. Erickson, T.O.; Stefan, H.G. Natural Groundwater Recharge Response to Urbanization: Vermillion River Watershed, Minnesota. J. Water Res. Plan Manag. 2009, 135, 512-520. [CrossRef]

3. Paul, M.J.; Meyer, J.L. Streams in the Urban Landscape. Annu. Rev. Ecol. Syst. 2001, 32, 333-365. [CrossRef] 
4. $\quad$ Davis, A.P.; Shokohian, M.; Himanshu, S.; Minami, C. Water Quality Improvement Through Bioretention Media: Nitrogen and P Removal. Water Environ. Res. 2006, 78, 284-293. [CrossRef] [PubMed]

5. Dietz, M.E.; Clausen, J.C. A Field Evaluation of Rain Garden Flow and Pollutant Treatment. Water Air Soil Pollut. 2005, 167, 123-138. Available online: https://link.springer.com/content/pdf/10.1007\%2Fs11270-005-826 6-8.pdf (accessed on 2 May 2019). [CrossRef]

6. Davis Davis, A.P.; Hunt, W.F.; Traver, R.G.; Clar, R.M. Bioretention Technology: Overview of Current Practice and Future Needs. J. Environ. Eng. 2009, 135, 109-117. [CrossRef]

7. U.S. Environmental Protection Agency 2009. Nitrogen and P Loads in Large Rivers. Available online: https://cfpub.epa.gov/roe/indicator_pdf.cfm?i=33 (accessed on 2 May 2019).

8. Mueller, D.K.; Helsel, D.R. Nutrients in the Nation's Waters, Too Much of a Good Thing? USGS NAWQA CIRC1136. Available online: http://pubs.usgs.gov/circ/circ1136/ (accessed on 2 May 2019).

9. Carpenter, S.R.; Caraco, N.F.; Correll, D.L.; Howarth, R.W.; Sharpley, A.N.; Smith, V.H. Nonpoint Pollution of Surface Qaters with P and Nitrogen. Ecol. Appl. 1998, 8, 559-568. Available online: https://esajournals.onlinelibrary.wiley.com/doi/pdf/10.1890/1051-0761\%281998\%29008\%5B0559\% 3ANPOSWW\%5D2.0.CO\%3B2 (accessed on 2 May 2019). [CrossRef]

10. LeFevre, G.H.; Paus, K.H.; Natarajan, P.; Gulliver, J.S.; Novak, P.J.; Hozalski, R.M. Review of Dissolved Pollutants in Urban Storm Water and Their Removal and Fate in Bioretention Cells. J. Environ. Eng. 2015, 141, 04014050. [CrossRef]

11. LeBleu, C.; Dougherty, M.; Rahn, K.; Wright, A.; Bowen, R.; Wang, R.; Orjuela, J.; Britton, K. Quantifying Thermal Characteristics of Stormwater through Low Impact Development Systems. Hydrology 2019, 6, 16. [CrossRef]

12. Thiagarajan, M.; Newman, G.; Zandt, S. The Projected Impact of a Neighborhood-Scaled Green-Infrastructure Retrofit. Sustainability 2018, 10, 3665. [CrossRef]

13. Yang, Y.-Y.; Toor, G.S. Stormwater Runoff Driven P Transport in an Urban Residential Catchment: Implications for Protecting Water Quality in Urban Watersheds. Sci. Rep. 2018, 8, 11681. [CrossRef] [PubMed]

14. Guillette, A. Low Impact Development Technologies: WBDG Whole Building Design Guide; National Institute of Building Sciences: Washington, DC, USA, 2016; Available online: https://www.wbdg.org/resources/low-imp act-development-technologies (accessed on 12 February 2019).

15. Low Impact Development Center. Urban Design Tools. Available online: https://www.lid-stormwater.net/b ackground.htm (accessed on 2 May 2019).

16. Monk, E.; Chalmers, L. Mimic Natural Drainage Processes: A Practical Approach for Stormwater Management in Western Australia. In Proceedings of the 1st National Hydropolis Conference Burswood Convention Centre Perth, Canberra, Australia, 8-11 October 2006; p. 16. Available online: https://www.water.wa.gov.au/ _data/assets/pdf_file/0018/5148/89891.pdf (accessed on 5 May 2019).

17. Kim, S.; Lee, S.-W.; Lee, J.; An, K. Exploring the Relationship between Prior Knowledge on Rain Gardens and Supports for Adopting Rain Gardens Using a Structural Equation Model. Sustainability 2018, 10, 1500. [CrossRef]

18. Newburn, D.A.; Alberini, A. Household Response to Environmental Incentives for Rain Garden Adoption. Water Resour. Res. 2016, 52, 1345-1357. [CrossRef]

19. Church, S. Exploring Green Streets and Rain Gardens as Instances of Small Scale Nature and Environmental Learning Tools. Landsc. Urban Plan 2015, 134, 229-240. [CrossRef]

20. Pak, G.; Park, H.; Cho, Y.; Kim, S. The Removal of Nutrients and Heavy Metals Using Household Rain garden. J. Wetl. Res. 2015, 17, 38-44. [CrossRef]

21. Smith, C.; Dunnett, N.; Clayden, A. Residential Landscape Sustainability: A Checklist Tool; Blackwell Publishing: Oxford, UK, 2008; p. 208. ISBN 978-1405158732.

22. Dietz, M.E. Low Impact Development Practices: A Review of Current Research and Recommendations for Future Directions. Water Air Soil Pollut. 2007, 186, 351-363. [CrossRef]

23. Prince George's County, Maryland. Bioretention Design Specifications and Criteria. Prince George's County, MD, USA. Available online: http://www.leesburgva.gov/home/showdocument?id=5057 (accessed on 2 May 2019).

24. Schueler, T.R. Comparative Pollutant Removal Capability of Urban BMPs: A Reanalysis. Watershed Prot. Tech. 1997, 2, 515-520. 
25. Steuer, J.; Selbig, W.; Hornewer, N.; Prey, J. Sources of Contamination in An Urban Basin in Marquette, Michigan and An Analysis of Concentrations, Loads, and Data Quality. USGS Water Res. Invest. Rpt. 1997, 42, 42. Available online: https://doi.org/10.3133/wri974242 (accessed on 2 May 2019).

26. Virginia Department of Forestry. Rain Gardens. Available online: http://www.dof.virginia.gov/manage/ripa rian/rain-gardens.htm (accessed on 2 May 2019).

27. Waschbusch, R.J.; Selbig, W.R.; Bannerman, R.T. Sources of P in Stormwater and Street Dirt from Two Urban Residential Basins in Madison, Wisconsin. Available online: https://pubs.er.usgs.gov/publication/wri994021 (accessed on 2 May 2019).

28. Dobbie, M. Designing Raingardens for Community Acceptance; Cooperative Research Centre for Water Sensitive Cities: Melbourne, Australia. Available online: https://watersensitivecities.org.au/wp-content/upl oads/2016/06/TMR_A4-1_2016_Designing_raingardens_web.pdf (accessed on 4 May 2019).

29. American Rivers. How Do Rain Garden And Rain Barrel Initiatives Help Rivers. Available online: file://C:/Users/leblecm/Zotero/storage/8RYD4AT2/rain-barrel-garden.html (accessed on 2 May 2019).

30. Paus, K.H.; Morgan, J.; Gulliver, J.S.; Hozalski, R.M. Effects of Bioretention Media Compost Volume Fraction on Toxic Metals Removal, Hydraulic Conductivity, and Phosphorous Release. J. Environ. Eng. 2014, 140, 04014033. [CrossRef]

31. Anderson, D.M.; Burkholder, J.M.; Cochlan, W.P.; Glibert, P.M.; Gobler, C.J.; Heil, C.A.; Kudela, R.M.; Parsons, M.L.; Rensel, J.E.J.; Townsend, D.W. Harmful Algal Blooms and Eutrophication: Examining Linkages from Selected Coastal Regions of the United States. Harmful Algae 2008, 8, 39-53. [CrossRef]

32. Correll, D.L. The Role of P in the Eutrophication of Receiving Waters: A Review. J. Envirnon. Qual. 1998, 27, 261. [CrossRef]

33. Riley, E.; Kraus, H.; Bilderback, T.; Owen, J.; Hunt, W. Impact of Engineered Filter Bed Substrate Composition and Plants on Stormwater Remediation within a Rain Garden System. J. Environ. Hortic. 2018, 36, 30-44.

34. Kraus, H.; Bilderback, T.; Pledger, R.; Riley, E.; Fonteno, B.; Jackson, B. Defining Rain Garden Filter Bed Substrates Based on Saturated Hydraulic Conductivity. Acta Hortic. 2014, 1034, 57-64. [CrossRef]

35. Kraus, H.; Spafford, A. Rain Gardening in the South: Ecologically Designed Gardens for Drought, Deluge and Everything in between; Eno Publishers: Hillsborough, NC, USA, 2009; p. 143. ISBN 978-0982077108.

36. Seymour, R.M. Capturing Rainwater to Replace Irrigation Water for Landscapes: Rain Harvesting and Rain gardens. In Proceedings of the Georgia Water Resources Conference, Athens, GA, USA, 25-27 April 2005; Available online: http://www.gwri.gatech.edu/sites/default/files/files/docs/2005/seymourR-GWRCpaper\%20 March21.pdf (accessed on 2 May 2019).

37. Dussaillant, A.R.; Cuevas, A.; Potter, K.W. Raingardens for Stormwater Infiltration and Focused Groundwater Recharge: Simulations for Different World Climates. Water Sci. Technol. Water Supply 2005, 5, 173-179. [CrossRef]

38. Clayden, A.; Dunnett, N. Rain Gardens: Managing Water Sustainably in the Garden and Designed Landscape; Timber Press: Portland, OR, USA, 2007; p. 188. ISBN 978-0881928266.

39. Steiner, L.M.; Domm, R.W. Rain Gardens: Sustainable Landscaping for a Beautiful Yard and a Healthy World; Voyageur Press: Minneapolis, MN, USA, 2012; p. 192. ISBN 0760340447.

40. Toran, L. Storm Water Control Management \& Monitoring; PA DOT: Harrisburg, PA, USA, 2017. Available online: https://rosap.ntl.bts.gov/view/dot/35094 (accessed on 3 May 2019).

41. Jackson, M.B.; Colmer, T.D. Response and Adaptation by Plants to Flooding Stress. Ann. Bot. 2005, 96, 501-505. [CrossRef] [PubMed]

42. Blom, C.W.P.M.; Voesenek, L.A.C. Flooding: The Survival Strategies of Plants. Trends Ecol. Evol. 1996, 11, 290-295. [CrossRef]

43. Crawford, R.M.M.; Braendle, R. Oxygen Deprivation Stress in a Changing Environment. J. Exp. Bot. 1996, 47, 145-159. [CrossRef]

44. Crawford, R.M.M. Whole Plant Adaptations to Fluctuating Water Tables. Folia Geobot. Phytotaxon. 1996, 31, 7-24. Available online: https://link.springer.com/content/pdf/10.1007\%2FBF02803990.pdf (accessed on 3 May 2019). [CrossRef]

45. Pociecha, E.; Kościelniak, J.; Filek, W. Effects of Root Flooding and Stage of Development on the Growth and Photosynthesis of Field Bean. Acta Physiol. Plant. 2008, 30, 529-535. [CrossRef]

46. Vartapetian, B.B.; Jackson, M.B. Plant Adaptations to Anaerobic Stress. Ann. Bot. 1997, 79, 3-20. [CrossRef] 
47. Kramer, P.J. Causes of Injury to Plants Resulting from Flooding of the Soil. Plant Physiol. 1951, 26, 722-736. Available online: https://www.ncbi.nlm.nih.gov/pmc/articles/PMC437542/pdf/plntphys00258-0086 .pdf (accessed on 3 May 2019). [CrossRef] [PubMed]

48. Mielke, M.S.; de Almeida, A.-A.F.; Gomes, F.P.; Aguilar, M.A.G.; Mangabeira, P.A.O. Leaf Gas Exchange, Chlorophyll Fluorescence and Growth Responses of Genipa americana Seedlings to Soil Flooding. Environ. Exp. Bot. 2003, 50, 221-231. [CrossRef]

49. Yordanova, R.Y.; Uzunova, A.N.; Popova, L.P. Effects of Short-Term Soil Flooding on Stomata Behavior and Leaf Gas Exchange in Barley Plants. Biol. Plant. 2005, 49, 317-319. [CrossRef]

50. Jing, Y.X.; Li, G.L.; Gu, B.H.; Yang, D.J.; Xiao, L.; Liu, R.X.; Peng, C.L. Leaf Gas Exchange, Chlorophyll Fluorescence and Growth Responses of Melaleuca alternifolia Seedlings to Flooding and Subsequent Recovery. Photosynthetica 2009, 47, 595-601. [CrossRef]

51. McJannet, C.L.; Keddy, P.A.; Pick, F.R. Nitrogen and P Tissue Concentrations in 41 Wetland Plants: A Comparison Across Habitats and Functional Groups. Funct. Ecol. 1995, 9, 231-238. [CrossRef]

52. Chen, H.; Qualls, R.G.; Blank, R.R. Effect of Soil Flooding on Photosynthesis, Carbohydrate Partitioning and Nutrient Uptake in the Invasive Exotic Lepidium latifolium. J. Aquat. Biol. 1995, 82, 250-268. [CrossRef]

53. Rubio, G.; Oesterheld, M.; Alvarez, C.R.; Lavado, R. Mechanisms for the Increase in P Uptake of Waterlogged Plants: Soil P Availability, Root Morphology and Uptake Kinetics. Oecologia 1997, 112, 150-155. [CrossRef]

54. Olila, O.G.; Reddy, K.R.; Stites, D.L. Influence of Draining on Soil P Forms and Distribution in a Constructed Wetland. J. Ecol. Eng. 1997, 9, 157-169. [CrossRef]

55. Jernigan, K. Nutrient Uptake and Plant Selection in Southeastern Rain Gardens. Master's Thesis, Auburn University, Auburn, AL, USA, 2010.

56. Akan, A. Preliminary Design Aid for Bioretention Filters. J. Hydrol. Eng. 2013, 18, 318-323. [CrossRef]

57. Turk, R.L.; Kraus, H.T.; Bilderback, T.E.; Hunt, W.F.; Fonteno, W.C. Rain Garden Filter Bed Substrates Affect Stormwater Nutrient Remediation. HortScience 2014, 49, 645-652. [CrossRef]

58. Jernigan, K.J.; Wright, A.N. Effect of Repeated Short Interval Flooding Events on Root and Shoot Growth of Four Landscape Shrub Taxa. J. Environ. Hort. 2011, 29, 220. [CrossRef]

59. Christian, K.J.; Wright, A.N.; Sibley, J.L.; Brantley, E.F.; Howe, J.A.; Dougherty, M.; LeBleu, C. Effect of P Concentration on Growth of Muhlenbergia capillaris in Flooded and Non-Flooded Conditions. J. Environ. Hort. 2012, 30, 219-222. [CrossRef]

60. Dylewski, K.L.; Wright, A.N.; Tilt, K.M.; LeBleu, C. Effect of Previous Flood Exposure on Flood Tolerance and Growth of Three Landscape Shrub Taxa Subjected to Repeated Short-Term Flooding. J. Environ. Hort. 2012, 30, 58-64. [CrossRef]

61. Meder, A. Flooding Tolerance and P Uptake of Southeastern Native Plants in Bioretention Gardens. Master's Thesis, Auburn University, Auburn, AL, USA, 2013.

62. Morash, J. Flooding Tolerance of Six Native Landscape Plants for Use in Southeastern Rain Gardens. Master's Thesis, Auburn University, Auburn, AL, USA, 2016.

63. Dewar, J.A. Perennial Polyculture Farming: Seeds of Another Agricultural Revolution? Rand Corp: Santa Monica, CA, USA, 2007; No. RAND/OP-179-RPC; Available online: https://www.rand.org/content/dam/rand/pubs/o ccasional_papers/2007/RAND_OP179.pdf (accessed on 3 May 2019).

64. Bracken, M.E.S. Monocultures Versus Polycultures; Encyc. Ecol. Elsevier: Oxford, UK, 2008; pp. $2446-2449$.

65. Kuhn, I.; Klotz, S. Urbanization and Homogenization - Comparing the Floras of Urban and Rural Areas in Germany. Biol. Conserv. 2006, 127, 292-300. Available online: https://www.ufz.de/export/data/2/92437_kue hn_urbanization_homogenization_BiolCons.pdf (accessed on 3 May 2019). [CrossRef]

66. Dudley, S.A.; File, A.L. Kin Recognition in an Annual Plant. Biol. Lett. 2007, 3, 435-438. [CrossRef] [PubMed]

67. Karathanasis, A.D.; Potter, C.L.; Coyne, M.S. Vegetation Effects on Fecal Bacteria, BOD, and Suspended Solid Removal in Constructed Wetlands Treating Domestic Wastewater. Ecol. Eng. 2003, 20, 157-169. [CrossRef]

68. Liang, M.-Q.; Zhang, C.-F.; Peng, C.-L.; Lai, Z.-L.; Chen, D.-F.; Chen, Z.-H. Plant Growth, Community Structure, and Nutrient Removal in Monoculture and Mixed Constructed Wetlands. Ecol. Eng. 2011, 37, 309-316. [CrossRef]

69. Calheiros, C.S.C.; Bessa, V.S.; Mesquita, M.B.R.; Brix, H.; Rangel, A.O.S.S.; Castro, P.M.L. Constructed Wetland with a Polyculture of Ornamental Plants for Wastewater Treatment at a Rural Tourism Facility. Ecol. Eng. 2015, 79, 1-7. [CrossRef] 
70. Turk, R.L.; Kraus, H.T.; Hunt, W.F.; Carmen, N.B.; Bilderback, T.E. Nutrient Sequestration by Vegetation in Bioretention Cells Receiving High Nutrient Loads. J. Environ. Eng. 2016, 143, 06016009. [CrossRef]

71. Alabama Cooperative Extension System (ACES). Alabama Smart Yards. 27 October. Available online: https://www.slideshare.net/Sotirakou964/alabama-smart-yards (accessed on 3 May 2019).

72. North Carolina Cooperative Extension (NCCE). Plants for rain gardens. Available online: https://brunswick. ces.ncsu.edu/wp-content/uploads/2017/11/RAINGARDENS_2017.pdf?fwd=no (accessed on 3 May 2019).

73. Logsdon, S. Nutrient Leaching When Soil Is Part of Plant Growth Media. Water 2017, 9, 501. [CrossRef]

74. Hunt, W.F.; Lord, W.G. Urban Waterways: Bioretention Performance, Design, Construction, and Maintenance; AGW-588-05; North Carolina State University: Raleigh, NC, USA, 2006; Available online: https://content.ces.ncsu.edu/static/publication/js/pdf_js/web/viewer.html?slug=bioretention-performa nce-design-construction-and-maintenance (accessed on 6 May 2019).

75. Liu, J.; Sample, D.J.; Owen, J.S.; Li, J.; Evanylo, G. Assessment of Selected Bioretention Blends for Nutrient Retention Using Mesocosm Experiments. J. Environ. Qual. 2014, 43, 1754. [CrossRef] [PubMed]

76. Palmer, E.T.; Poor, C.J.; Hinman, C.; Stark, J.D. Nitrate and Phosphate Removal through Enhanced Bioretention Media: Mesocosm Study. Water Environ. Res. 2013, 85, 823-832. [CrossRef] [PubMed]

77. Wright, R.D. The pour-through nutrient extraction procedure. HortScience 1986, 21, 227-229.

78. Hue, N.V.; Evans, C.E. Procedures Used for Soil and Plant Analysis by th Auburn University Soil Testing Laboratory. Agron. Soils Dep. Ser. 1986, 1-12.

79. Whitlock, M.; Schluter, D. The Analysis of Biological Data; Roberts \& Company Publishers: Greenwood Village, CO, USA, 2009; p. 864. ISBN 978-1936221486.

80. Colmer, T.D. Aerenchyma and An Inducible Barrier to Radial Oxygen Loss Facilitate Root Aeration in Upland, Paddy and Deep-water Rice (Oryza sativa L.). Ann. Bot. 2002, 91, 301-309. [CrossRef] [PubMed]

81. Choi, B.; Dewey, J.C.; Hatten, J.A.; Ezell, A.W.; Fan, Z. Changes in Vegetative Communities and Water Table Dynamics Following Timber Harvesting in Small Headwater Streams. For. Ecol. Manag. 2012, 281, 1-11. [CrossRef]

82. United States Department of Agriculture. Plants Database. Conservation Plant Characteristics: Coreopsis verticillate L. Available online: http://plants.usda.gov/java/charProfile?symbol=COLA5 (accessed on 14 May 2019).

83. Thetford, M.; Norcini, J.G.; Ballard, B.; Aldrich, J.H. Ornamental Landscape Performance of Native and Nonnative Grasses Under Low-input Conditions. HortTechnology 2009, 19, 267-285. [CrossRef]

84. Byun, C.; de Blois, S.; Brisson, J. Plant Functional Group Identity and Diversity Determine Biotic Resistance to Invasion by an Exotic Grass. J. Ecol. 2012, 101, 128-139. [CrossRef]

85. Pokorny, M.L.; Sheley, R.I.; Zabinski, C.A.; Engel, R.E.; Svejcar, T.J.; Borkoski, J.J. Plant Functional Group Diversity as a Mechanism for Invasion Resistance. Restor. Ecol. 2005, 13, 448-459. [CrossRef]

86. Sphen, E.M.; Joshi, J.; Schmid, B.; Diemer, M.; Korner, C. Above Ground Resource Use Increases with Plant Species Richness in Experimental Grassland Ecosystem. Funct. Ecol. 2001, 14, 326-337. [CrossRef]

87. Chapin, F.S. The Mineral Nutrition of Wild Plants. Annu. Rev. Ecol. Syst. 1980, 11, 233-260. [CrossRef]

88. Grime, J.P. Evidence for the Existence of Three Primary Strategies in Plants and its Relevance to Ecological and Evolutionary Theory. Am. Nat. 1977, 111, 1169-1194. [CrossRef]

89. Parsons, R.F. The Significance of Growth-Rate Comparisons for Plant Ecology. Am. Nat. 1968, 102, 595-597. [CrossRef]

90. Read, J.; Wevill, T.; Fletcher, T.; Deletic, A. Variation Among Plant Species in Pollutant Removal from Stormwater in Biofiltration Systems. Water Res. 2008, 42, 893-902. [CrossRef] [PubMed]

91. Vance, C.P.; Uhde-Stone, C.; Allen, D.I. P Acquisition and Use: Critical Adaptations by plants for Securing a Nonrenewable Resource. New Phytol. 2003, 157, 423-447. [CrossRef]

92. Milla, R.; Forero, D.M.; Escuder, A.; Iriondo, J.M. Growing with Siblings: A Common Ground for Cooperation or for Fiercer Competition Among Plants? Proc. R. Soc. B Biol. Sci. 2009, 276, 2531-2540. [CrossRef] [PubMed]

93. Kozlowski, T.T. Plant Responses to Flooding of Soil. Biol. Sci. 1984, 34, 162-167. [CrossRef]

94. Kozlowski, T.T. Responses of Woody Plants to Flooding and Salinity. Tree Phys. Mongr. 1997, 1, 1-29. Available online: https://www.scirp.org/(S(351jmbntvnsjt1aadkposzje))/reference/ReferencesPapers.aspx?Ref erenceID=424063 (accessed on 14 May 2019). [CrossRef]

95. Li, S.; Pezeshki, S.R.; Goodwin, S. Effects of Soil Moisture Regimes on Photosynthesis and Growth in Cattail (Typha latifolia). Acta Oecol. 2004, 25, 17-22. [CrossRef] 
96. Rouse, S.E. Effects of Vegetation Type on the Hydrologic Budget and Inorganic Nitrogen in Recently Established Rain Gardens. Master's Thesis, University of Wisconsin, Madison, WI, USA, 2007.

97. Dougherty, M.; LeBleu, C.; Brantley, E.; Francis, C. Evaluation of Bioretention Nutrient Removal in a Rain Garden with an Internal Water Storage (IWS) Layer. In Proceedings of the ASABE Annual International Conference, Minneapolis, MN, USA, 17-20 June 2007. 